\title{
Análise da conformidade na adoção das normas de produção integrada de pêssego
}

\author{
Analysis of the conformity in the adoption of the norms of integrated production of peach
}

\author{
Casiane Salete Tibola ${ }^{1}$ José Carlos Fachinello ${ }^{\mathrm{I}}$ Cesar Valmor Rombaldi ${ }^{\mathrm{I}}$ \\ Luciano Picolotto ${ }^{\mathrm{I}}$ Leandro Krüger ${ }^{\mathrm{I}}$
}

\begin{abstract}
- NOTA -
RESUMO

O presente trabalho objetivou avaliar o grau de conformidade dos pomares de pêssego às Normas de Produção Integrada de Pêssego (PIP), a fim de assegurar a qualidade e a segurança dos produtos obtidos, para tornar a cadeia produtiva mais competitiva no mercado. A implementação da PIP e da rastreabilidade na produção foi realizada através de visitas mensais, a partir do início do ciclo vegetativo até a póscolheita. Paralelamente à implementação da PIP e do sistema de rastreabilidade, foram realizadas auditorias internas, para avaliar as condições de produção, transporte e armazenamento, através das listas de verificação para auditoria de adesão e de acompanhamento. O percentual de fruticultores que estão em

through monthly visits, starting from the beginning of the vegetative cycle to after harvest. Parallel to the implementation of IPP and traceability system, internal auditings were accomplished to evaluate the conditions of productions, transport and storage, through verification lists for adhesion and attendance auditing. The percentage of producers that are in accordance with the demands of IPP is $30 \%$. The cultural treatments extolled by IPP which are being adopted are: green pruning, maintenance of the covering in the soil, balanced fertilization, use of allowed pesticides and devolution of empty packings. For the consolidating of the integrated production, it is needed to enlarge the orientation for the integrated handling of curses and diseases, as well as the technology of pesticides application.
\end{abstract} conformidade com as exigências da PIP é de 30\%. Dentre os tratos culturais preconizados pela PIP que estão sendo adotados, destacam-se: poda verde, manutenção da cobertura no solo, adubação equilibrada, utilização de agrotóxicos permitidos e devolução de embalagens vazias. Para a consolidação da produção integrada, há a necessidade de ampliar a orientação quanto ao manejo integrado de pragas e doenças, bem como quanto à tecnologia de aplicação de agrotóxicos.

Palavras-chave: Prunus persica L. Batsch, selo de conformidade, tratos culturais.

\section{ABSTRACT}

This research was aimed at evaluating the conformity degree of the peach orchards to the Norms of Integrated Peach Production (IPP), in order to assure quality and safety of the products obtained and to turn the productive chain more competitive in the market. The implementation of IPP and traceability in the production was accomplished
Key words: Prunus persica L. Batsch, conformity stamp, cultural treatments.

O mercado de alimentos está progressivamente mais competitivo e os consumidores demonstram crescente sensibilidade quanto aos fatores ambientais, sociais e nutricionais, promovendo mudanças nos hábitos de consumo. Esta maior preocupação provoca a geração de tecnologias limpas e sustentáveis na produção, além da comprovação da qualidade e procedência dos produtos. Nesse sentido, a produção controlada desde a origem, em conformidade com os conceitos de produção integrada e rastreabilidade, passa a ser decisiva para a competitividade no mercado (FACHINELLO et al., 2004).

IFruticultura de Clima Temperado, Departamento de Fitotecnia, Faculdade de Agronomia Eliseu Maciel, Universidade Federal de Pelotas (FAEM/UFPel). Rua Félix da Cunha, 814/101, 96010-000, Pelotas, RS, Brasil. E-mail: cstibola@yahoo.com.br. Autor para correspondência.

IIDepartamento de Ciência e Tecnologia Agroindustrial, FAEM/UFPel, Pelotas, RS, Brasil. 
No ano de 2005, a área cultivada com produção integrada (PI) no Brasil foi de 35.508 hectares, com produção de 1.094.615 toneladas, distribuídas entre dezessete espécies frutíferas e envolvendo 1.002 produtores (ANDRIGUETO \& KOSOSKI, 2005). Os principais resultados obtidos pela produção integrada de frutas (PIF) no Brasil são: o aumento de emprego e renda; a redução das pulverizações; a diminuição de resíduos químicos nas frutas; e a melhoria na qualidade do produto.

A produção brasileira de pêssego é de 146 mil toneladas anuais. O Rio Grande do Sul é o principal produtor, possuindo uma área de 12.390 hectares e alcançando uma produção de 96.567 toneladas anuais (JOÃO, 2004). No ciclo agrícola 2004/05, a Produção Integrada de Pêssego (PIP) envolveu 105 produtores, em uma área de 520ha, e produção de 6.240 toneladas (ANDRIGUETO \& KOSOSKI, 2005). Os principais avanços tecnológicos observados foram: melhoria organizacional da base produtiva, capacitação técnica, incremento da qualidade, minimização do impacto ambiental, além da maior competitividade entre os produtos, em virtude de sua maior acessibilidade ao mercado.

Nesse contexto, foi realizado um trabalho com objetivo de avaliar o grau de conformidade dos pomares de pêssego às Normas PIP, a fim de assegurar a qualidade e a segurança dos produtos obtidos.

O trabalho foi iniciado em 2002, na Indústria de Conservas Irmãos Oderich Ltda, e, posteriormente, engajaram-se outras duas indústrias: Indústria de Conservas Minuano Ltda e Indústria de Conservas Leon Ltda, além da Cooperativa dos Fruticultores do Sul (Cooperfrutis). Em 2002, a implementação da PIP e do sistema de rastreabilidade envolveu cinco produtores, nos anos subseqüentes, ampliada para 13 e 25 produtores, sendo, respectivamente. Esses produtores passaram a receber visitas técnicas mensais, desde o início do ciclo vegetativo até a pós-colheita.

A avaliação da conformidade foi realizada paralelamente à implementação da PIP, e a rastreabilidade através de auditorias internas para avaliar as condições de produção, transporte e armazenamento, através das listas de verificação para auditoria de adesão e de acompanhamento das normar PIP.

Foi analisado o grau de conformidade do manejo adotado, abrangendo as seguintes áreas temáticas: capacitação; recursos naturais; material propagativo; implantação de pomares; nutrição das plantas; manejo do solo; manejo da parte aérea; proteção integrada da cultura; colheita e pós-colheita; sistema de rastreabilidade, e assistência técnica. Nesta etapa, além de identificarem-se as não-conformidades, foram sugeridas adequações pertinentes, objetivando a preparação da cadeia produtiva para o atendimento dos requisitos estabelecidos nas Normas PIP, com vistas à futura certificação e à obtenção do selo de qualidade.

Quanto à sanidade das plantas, os principais problemas detectados, no período 2002/04, foram: bacteriose [Xantomonas arboricola pv. Pruni (E. F. Smith)] e podridão parda [Monilinia fructicola (Wint.) Honey]. Durante os anos mais chuvosos (2002) e quentes (2002 e 2003), houve incidência de antracnose [Glomerella cingulata (Stoneman) Spauld. \& H. Schrenk] no início do ciclo vegetativo.

A podridão parda é a principal doença do pessegueiro na região, sendo que as fases de maior suscetibilidade são a floração e a pré-colheita. As recomendações para controle cultural consistiram no tratamento de inverno e na poda de limpeza, com eliminação de ramos doentes, restos florais e frutos mumificados. O controle dos insetos-praga, que ocasionam ferimentos nos frutos e atuam como vetores, é essencial para o controle da podridão parda. $\mathrm{O}$ controle químico da doença, no ciclo vegetativo, deve ser iniciado na fase de botão rosado até a colheita, dependendo das condições climáticas (MAY DE MIO et al., 2004).

Para padronizar a coleta de informações, determinou-se a seguinte classificação: baixa produtividade: $<10 \mathrm{t} \mathrm{ha}^{-1}$; média produtividade: $10 \mathrm{a}$ $15 \mathrm{tha}^{-1}$; e alta produtividade: $>15 \mathrm{t} \mathrm{ha}{ }^{-1}$. Os pomares apresentam grande variabilidade na produtividade, devido aos fatores geomorfológicos e ao manejo adotado. Verificou-se que os tratos culturais (poda, raleio, fertilização e aplicação de agrotóxicos), quando realizados no período recomendado, influenciaram substancialmente na produtividade e no custo de produção do pomar.

Na safra 2002/03, a precipitação pluviométrica, no período de setembro/2002 a janeiro/ 2003, foi de 538mm, dificultando o manejo das doenças como a podridão parda e a bacteriose, ocasionando menor produtividade. Também nessa safra, no mês de novembro, ocorreram fortes ventos $\left(>100 \mathrm{~km} \mathrm{~h}^{-1}\right)$, que ocasionaram queda de folhas, frutos e quebra de ramos, gerando perdas de até $50 \%$ da produção, nos pomares mais expostos e/ou sem quebra-ventos.

Em 2002, o gorgulho do milho (Sitophilus zeamais Mots) apresentou alta incidência nos pomares, principalmente na segunda quinzena de dezembro. As perdas ocorreram pela queda dos frutos, o que gerou prejuízos à sua aparência e ferimentos, além de infecções fúngicas. 
Na safra 2003/04, foi obtida a maior produtividade média $\left(15 \mathrm{t} \mathrm{ha}^{-1}\right)$, sobretudo pela regularidade das chuvas no período vegetativo e pela diminuição da freqüência no período de amadurecimento, garantindo boa sanidade e colheita no período de maturação adequado.

Na safra 2004/05, ocorreu uma alta incidência de mosca-das-frutas (Anastrefa fraterculus Wied), que provocou uma quebra de safra de $30 \%$, atingindo, principalmente, as cultivares de ciclo precoce e médio. Essas perdas devem-se, basicamente, às condições climáticas, que favoreceram a grande proliferação da praga; à disponibilidade de habitat para proliferação em fruteiras nativas e nas frutas temporonas; ao início tardio do monitoramento e à falta de aplicações de iscas tóxicas nas bordas dos pomares.

Segundo BOTTON et al. (2004), para a realização do manejo adequado da mosca-das-frutas e da grafolita (Grafolita molesta Busk), é fundamental realizar o monitoramento. As armadilhas para moscadas-frutas devem ser instaladas quatro a cinco semanas após a plena floração, em locais onde há maior probabilidade de captura, como na periferia dos pomares e próximo às bordaduras com matas. Para grafolita, as armadilhas devem ser instaladas no pomar no início da brotação.

Em alguns pomares analisados, foi adotada a condução das plantas em "Y" ou "V", reduzindo-se o espaçamento e aumentando-se a densidade de plantas; porém, o manejo continuou sendo semelhante ao sistema tradicional em vaso, devido à falta de mão-deobra qualificada e à maior necessidade de poda verde. Com isso, as plantas apresentaram excesso de crescimento vegetativo, promovendo o sombreamento no interior da planta, dificultando a entrada dos agrotóxicos e propiciando o aumento da ocorrência de doenças, além de frutificação nas extremidades, dificultando a colheita.

O manejo do solo tem sido adequado na maioria dos pomares. Nos pomares novos, foram realizadas capinas, para evitar problemas de fitotoxidez causada pelos herbicidas. Realizou-se o manejo da cobertura verde na entrelinha, através de roçadas e, na linha, com a utilização de herbicidas, limitado a duas aplicações anuais. Os casos de não-conformidade ocorrem pela gradagem para incorporação de adubos.

A análise química do solo e a análise foliar não foram realizadas com a periodicidade recomendada, ou seja, a cada três anos e anualmente, respectivamente. Os principais critérios adotados para a adubação são o desenvolvimento vegetativo e a produtividade do pomar.
Detectou-se que a poda verde ainda não está sendo adequadamente realizada. Os fruticultores tratam como uma questão secundária de manejo no pomar, argumentando a falta de mão-de-obra na propriedade, principalmente no período de proximidade da colheita. Dessa forma, as plantas apresentam excesso de ramos no interior da copa, prejudicando a insolação e a eficiência na aplicação dos agrotóxicos.

A prática do raleio nem sempre foi realizada no período recomendado, ou seja, antes do início do endurecimento do caroço, que corresponde a 20-30 dias após a plena floração. Em alguns casos, a intensidade do raleio foi inadequada, ocasionando quebra de galhos e a produção de frutas de menor tamanho.

O monitoramento de pragas no pomar foi muito diferenciado entre as propriedades estudadas. Em algumas, foi realizado semanalmente conforme a recomendação porém, na maioria, realizaram-se contagens esporádicas dos insetos capturados nas armadilhas. Ao mesmo tempo, muitos fruticultores procederam à aplicação de isca tóxica nas bordas do pomar e de inseticidas na área total, desconsiderando os dados do monitoramento.

Em torno de 80\% dos fruticultores coletam a água através do coletor do pulverizador, diretamente nos córregos ou açudes, ocasionando contaminações, devido ao refluxo de calda no final da captação. Verificaram-se, também, contaminações no momento de preparo da calda, devido a derramamentos, muitos desses nas proximidades de fontes d'água.

Outro aspecto refere-se à destinação das embalagens vazias de agrotóxicos que, em 30\% dos casos, foram lavadas, porém permaneceram no próprio local de preparo. Outros fruticultores realizavam a tríplice lavagem, armazenando-as em sacos na propriedade. Aproximadamente $50 \%$ dos fruticultores devolviam as embalagens tríplices lavadas para as revendas de produtos agropecuários onde haviam adquirido, conforme recomendado.

A grande maioria (90\%) dos fruticultores não lava o pulverizador após o uso. Constatou-se falta de informação quanto à tecnologia de aplicação de agrotóxicos, quanto aos efeitos dos mesmos na saúde humana e ao seu potencial de contaminação do meio ambiente.

Quanto ao conhecimento, em relação aos agrotóxicos registrados para pessegueiro, verificouse que muitos agricultores conheciam os produtos mais antigos, mas poucos consultavam material técnico para atualização. As não-conformidades devido ao uso de agrotóxicos não permitidos foi generalizada. Os principais princípios ativos utilizados foram: fungicida Carbendazim (Derosal), aplicado principalmente na 
floração, e inseticida Dimetoate (Perfekthion), utilizado para controle de mosca-das-frutas.

Observaram-se variadas situações quanto à utilização de equipamentos de proteção individual (EPI); porém, na maioria das situações, o uso foi incorreto e/ou incompleto. Também não há uma rotina de aferição dos equipamentos de aplicação de agrotóxicos, a qual, em muitos casos, nunca foi realizada.

Os vasilhames de colheita utilizados, em geral, não são lavados e desisfestados, contribuindo para o aumento das doenças na pós-colheita. Além disso, a higiene dos colhedores também deve ser observada, para a minimização das perdas na fase de pós-colheita.

A maioria dos produtores não possui o hábito de registrar no caderno de campo os tratos culturais e a ocorrência de pragas e doenças no pomar, limitando o processo de rastreabilidade. O maior progresso foi obtido com aqueles produtores que aderiram ao projeto desde a fase inicial. Espera-se assim que, com treinamentos, visitas técnicas e dias de campo, esse procedimento seja amplamente adotado pelos fruticultores.

Para receber o selo de certificação da PIP, os fruticultores e industriais devem comprovar experiência mínima de um ciclo agrícola. Das indústrias e produtores integrantes desse projeto, 30\% estão em conformidade com as normas PIP e com condições de serem auditados e receberem o selo de certificação da PIP. Os demais participantes deverão adequar-se primeiramente às normas, para posterior auditoria e certificação.

Os tratos culturais preconizados pela PIP estão sendo adotados a partir do progresso nos conhecimentos e nas tecnologias geradas, destacandose: poda verde, manutenção da cobertura no solo, adubação equilibrada, utilização de agrotóxicos permitidos e devolução de embalagens vazias.

As principais necessidades para a consolidação da PIP incluem a ampliação da orientação quanto ao manejo integrado de pragas e doenças, assim como quanto à tecnologia de aplicação de agrotóxicos.

\section{REFERÊNCIAS}

ANDRIGUETO, J.R.; KOSOSKI, A.R. Desenvolvimento e Conquistas da Produção Integrada de Frutas no Brasil - até 2004. Relatório 2005. Brasília: Ministério da Agricultura, Pecuária e Abastecimento, 2005. 10p.

BOTTON, M. et al. Recomendações para o monitoramento da mosca-das-frutas sul americana e da mariposa oriental na produção integrada de pêssego. Bento Gonçalves - RS: Embrapa Uva e Vinho, 2004. 7p.

FACHINELLO, J.C. et al. Produção integrada de pêssego (PIP). In: MONTEIRO, L.B. et al. Fruteiras de caroço: uma visão ecológica. Curitiba: UFPR, 2004. p.363-390.

JOÃO, P.L. Levantamento da fruticultura comercial do Rio Grande do Sul -2003/2004. Porto Alegre: EMATER/RS - ASCAR, 2004. 89p.

MAY DE MIO, L.L. et al. Doenças de fruteiras de caroço. In: MONTEIRO, L.B. et al. Fruteiras de caroço: uma visão ecológica. Curitiba: UFPR, 2004. p.169-222. 